\title{
Mutations Affecting the Synthesis of NADP-dependent Glutamate Dehydrogenase in Pseudomonas aeruginosa
}

\author{
By CHRISTOPHER L. JOANNOU, PAUL R. BROWN* AND RENÉE TATA \\ Department of Biochemistry, King's College London, Strand, London WC2R 2LS, UK
}

(Received 8 June 1987; revised 24 August 1987)

\begin{abstract}
NADP-dependent glutamate dehydrogenase (NADP-GDH) was purified to homogeneity from Pseudomonas aeruginosa strain 8602 (PAC 1). The $M_{\mathrm{r}}$ determined by Sephadex gel filtration was 280000 ; the subunit $M_{\mathrm{r}}$ determined by SDS-PAGE was 45000 . Mutant strains lacking NADPGDH and glutamate synthase $\left(\mathrm{Gdh}^{-} \mathrm{Glt}^{-}\right)$required glutamate for growth. Transductants that lacked only NADP-GDH were indistinguishable from the wild-type strain in growth properties. It was concluded that NADP-GDH is not essential for growth of the wild-type organism and that glutamate formation via NAD-dependent glutamate dehydrogenase does not occur to a significant extent. A mutant strain, 39, producing high NADP-GDH activity, synthesized normal NADP-GDH and had the same intracellular glutamate concentrations as its parent. The mutation responsible for the synthesis of high levels of NADP-GDH was shown, by transduction, to be closely linked to the NADP-GDH structural gene $(g d h A)$.
\end{abstract}

\section{INTRODUCTION}

The formation of glutamate from exogenously supplied sources of nitrogen must be an important step in the biosynthesis of nitrogen compounds by Pseudomonas aeruginosa since mutant strains lacking glutamate synthase (EC 1.4.1.13), which catalyses the formation of glutamate from glutamine and 2-oxoglutarate with the oxidation of NADPH (Meers et al., 1970; Tempest et al., 1970), have a considerably reduced repertoire of utilizable nitrogen sources (Brown \& Tata, 1981). In the enteric organisms Klebsiella pneumoniae, Salmonella typhimurium and Escherichia coli, glutamate formation occurs via glutamate synthase or NADP-dependent glutamate dehydrogenase (NADP-GDH; EC 1.4.1.4), which catalyses glutamate formation from 2-oxoglutarate and ammonia with the oxidation of NADPH (Tyler, 1978). Either enzyme can function when excess ammonia is available for growth but when the ammonia concentration is growth-rate-limiting, even if NADP-GDH is functional, inactivation of glutamate synthase results in glutamate auxotrophy (Berberich, 1972; Brenchley \& Magasanik, 1974; Dendinger et al., 1980). Glutamate-synthase-negative mutants of $P$. aeruginosa grow when excess ammonia is available so it seems likely, by analogy with enteric organisms, that under these circumstances glutamate synthesis is catalysed by glutamate dehydrogenase. However, $P$. aeruginosa is relatively unusual among bacteria in producing two glutamate dehydrogenases, one NADdependent (NAD-GDH; EC 1.4.1.3), the other NADP-dependent (Brown et al., 1973). Although synthesis of NAD-GDH is unaffected by nitrogen limitation, synthesis of NADPGDH is regulated by the availability of ammonia, being repressed during nitrogen-limited growth and by the presence of glutamate in the growth medium, suggesting that it has a role in glutamate synthesis (Janssen et al., 1980; Brown \& Tata, 1981). Synthesis of NADP-GDH in $S$. typhimurium and $E$. coli is repressed by glutamate in the medium but nitrogen limitation has no

\footnotetext{
Abbreviations: NADP-GDH, NADP-dependent glutamate dehydrogenase; NAD-GDH, NAD-dependent glutamate dehydrogenase; GS, glutamine synthetase; PMS, phenazine methosulphate; MTT, 3-(4,5dimethylthiazol-2-yl)-2,5-diphenyltetrazolium bromide; NTG, $N$-methyl- $N^{\prime}$-nitrosoguanidine.
} 
effect. In $K$. aerogenes nitrogen limitation causes a decrease in NADP-GDH synthesis. The variation in patterns of regulation of synthesis of NADP-GDH has focussed interest on understanding the molecular basis for these differences (Mountain et al., 1985). In this paper we report on work done to determine the role of NADP-GDH in P. aeruginosa and to investigate a mutant strain in which NADP-GDH synthesis is apparently derepressed.

\section{METHODS}

Bacterial strains. The wild-type strain was $P$. aeruginosa strain 8602 (PAC 1) (Kelly \& Clarke, 1962). The origins and properties of the other strains used are listed in Table 1.

Media. Minimal media were prepared by the addition of carbon and nitrogen sources to minimal salts medium (Brammar \& Clarke, 1964). Sodium succinate (S), $0.5 \%(\mathrm{w} / \mathrm{v})$, was added to the medium before autoclaving. Nitrogen sources [ammonium sulphate $0.1 \%(\mathrm{w} / \mathrm{v})(\mathrm{N})$, or $0.01 \%(\mathrm{w} / \mathrm{v})(\mathrm{lowN})$, and sodium nitrate (nit) $0.1 \%$ $(w / v)]$ were added before autoclaving. L-Proline (Pro), $0.1 \%(w / v)$, sodium L-glutamate $(G l u), 0.1 \%(w / v)$, Lglutamine $(\mathrm{Gln}), 0.1 \%(\mathrm{w} / \mathrm{v})$, and $\mathrm{L}$-histidine (His) $0.1 \%(\mathrm{w} / \mathrm{v})$, were sterilized by filtration and added to autoclaved media. Nutrient medium was made with Oxoid Nutrient Broth no. 2. Solid media contained $1 \%(\mathrm{w} / \mathrm{v})$ Difco Noble Agar.

Bacterial growth and preparation of cell-free extracts. Bacteria used for enzyme purification were grown by inoculating batches of $300 \mathrm{ml}$ medium in 1 litre conical flasks with $0.1 \mathrm{ml}$ broth culture and shaking in a Galienkamp rotary shaker at $37^{\circ} \mathrm{C}$. Exponential phase cultures were grown to $\mathrm{OD}_{670}=0.35$; stationary phase cultures were normally grown for $15 \mathrm{~h}$. Bacteria were harvested by centrifugation and washed with dilution buffer (Brammar et al., 1967). Cells were resuspended in 1/100th the growth medium volume of $50 \mathrm{~mm}$-Tris $/ \mathrm{HCl}$ buffer, $\mathrm{pH} 7 \cdot 0$, and sonicated for $1 \mathrm{~min}$ at $0^{\circ} \mathrm{C}$ using an MSE Mullard ultrasonic disintegrator (power output $50 \mathrm{~W}$ ) in $20 \mathrm{~s}$ bursts. Cell debris was removed by centrifugation at $20000 \mathrm{~g}$ for $15 \mathrm{~min}$ at $4^{\circ} \mathrm{C}$. Extracts prepared from transductants to investigate the electrophoretic mobilities of NADP-GDHs were prepared from $10 \mathrm{ml}$ stationary phase cultures by resuspending the pellet obtained after centrifugation of overnight cultures in $0.2 \mathrm{ml}$ $50 \mathrm{mM}$-Tris $/ \mathrm{HCl}, \mathrm{pH} 7 \cdot 6$, at $4^{\circ} \mathrm{C}$, sonicating for $15 \mathrm{~s}$, then removing debris by centrifugation in an MSE microfuge at $4{ }^{\circ} \mathrm{C}$.

Purification of NADP-GDH. NADP-GDH was prepared from cells of strain 8602 grown in $201 \mathrm{~S} / \mathrm{N}$ medium, washed and stored as frozen pellets. The buffer used throughout was $50 \mathrm{~mm}-\mathrm{Tris} / \mathrm{HCl}, \mathrm{pH} 7.5$, containing $10 \mathrm{mM}$ mercaptoethanol. All operations were done at $4{ }^{\circ} \mathrm{C}$. Bacteria were thawed and resuspended in $200 \mathrm{ml} \mathrm{Tris} / \mathrm{HCl}$ buffer; cells were disrupted using an MSE ultrasonicator (power output $50 \mathrm{~W}$ ) for $1 \mathrm{~min}$ in $20 \mathrm{~s}$ bursts. Streptomycin sulphate $(2 \mathrm{~g})$ was added with stirring to precipitate nucleic acids; these and cell debris were removed by centrifugation at $22000 \mathrm{~g}$ for $20 \mathrm{~min}$.

Ammonium sulphate was added to the supernatant; precipitates obtained at $30,40,50,60,70$ and $80 \%$ saturation were removed by centrifugation and dissolved in Tris buffer. The $60 \%$ ammonium sulphate fraction, which contained the bulk of the NADP-GDH activity, was dialysed against Tris buffer and loaded onto a column $(4 \times 12 \mathrm{~cm})$ of DEAE Sepharose equilibrated with Tris buffer. The enzyme was eluted using a $0-0.5 \mathrm{~m}$ linear gradient of $\mathrm{KCl}$ in a total of 1 litre Tris buffer. A flow rate of $45 \mathrm{ml} \mathrm{h}^{-1}$ was maintained and $10 \mathrm{ml}$ fractions were collected. Fractions containing NADP-GDH eluted by $0.25 \mathrm{M}-\mathrm{KCl}$ were bulked and dialysed against Tris buffer.

The solution $(50 \mathrm{ml})$ containing enzyme was loaded onto a column $(1 \times 5 \mathrm{~cm})$ of Reactive Red 120 equilibrated with Tris buffer. The column was first washed with $20 \mathrm{ml}$ buffer to remove unbound protein then eluted with a linear $0-0.75 \mathrm{M}-\mathrm{KCl}$ gradient in $300 \mathrm{ml}$ Tris buffer. A flow rate of $10 \mathrm{ml} \mathrm{h}^{-1}$ was maintained and $2.7 \mathrm{ml}$ fractions were collected. Fractions containing NADP-GDH activity (eluting at $0.4 \mathrm{M}-\mathrm{KCl}$ ) were bulked and concentrated to $3 \mathrm{ml}$ by ultrafiltration in a $50 \mathrm{ml}$ Chemlab ultrafiltration apparatus fitted with an XM-10 membrane filter (Amicon) then dialysed against Tris buffer.

The solution of enzyme from the previous step was applied to a $2^{\prime}, 5^{\prime}$-ADP agarose column $(1 \times 1 \mathrm{~cm})$ equilibrated with Tris buffer. The column was washed with $3 \mathrm{ml}$ Tris buffer then eluted with a linear gradient of 0-1.2 mM-NADP ${ }^{+}$in $300 \mathrm{ml}$ Tris buffer. A flow rate of $10 \mathrm{ml} \mathrm{h}^{-1}$ was maintained and $2.7 \mathrm{ml}$ fractions were collected. Fractions containing NADP-GDH activity, eluted by $0.6 \mathrm{~mm}-\mathrm{NADP}+$, were bulked, concentrated by ultrafiltration, dialysed against Tris buffer and stored at $4{ }^{\circ} \mathrm{C}$ in Tris buffer containing $50 \%(\mathrm{v} / \mathrm{v})$ glycerol.

$M_{r}$ determination. The $M_{\mathrm{r}}$ of NADP-GDH was estimated by molecular sieve chromatography (Andrews, 1970) on a $2 \times 100 \mathrm{~cm}$ column of Sephadex G-200 standardized with the following marker proteins: cytochrome $c\left(M_{\mathrm{r}}\right.$ $12500)$; carbonic anhydrase (25000); ovalbumin (43000); bovine serum albumin (BSA) (68000); catalase (210000); and ferritin (440000).

Subunit $M_{r}$ determination. The subunit $M_{\mathrm{r}}$ of NADP-GDH was estimated by comparison of electrophoretic mobilities with those of marker proteins on an SDS-polyacrylamide $(5 \%, \mathrm{w} / \mathrm{v})$ gel prepared as described by Weber $\&$ Osborne (1969). Marker proteins were as follows: RNA polymerase $\beta^{\prime}$-subunit $\left(M_{\mathrm{r}} 165000\right)$, RNA polymerase $\beta$-subunit (155000), BSA (68000), RNA polymerase $\alpha$-subunit (39000); and trypsin inhibitor (21500). 


\section{Table 1. Bacterial strains}

GdhR- indicates derepression of NADP-GDH synthesis.

\begin{tabular}{|c|c|c|c|}
\hline Strain & $\begin{array}{l}\text { Genotype/ } \\
\text { phenotype }\end{array}$ & $\begin{array}{l}\text { Source/ } \\
\text { parent }\end{array}$ & Reference \\
\hline 8602 (PAC 1) & Wild-Type & NCIB & Kelly \& Clarke (1962) \\
\hline AIUIN & $\begin{array}{l}\text { Constitutive synthesis } \\
\text { of altered amidase }\end{array}$ & L10 & Gregoriou et al. (1977) \\
\hline SU4 & $\mathrm{Glt}^{-} \mathrm{Gdh}^{+}$ & 8602 & Brown \& Tata (1981) \\
\hline SU1 & $\mathrm{Glt}^{-} \mathrm{Gdh}^{+}$ & AIUIN & Brown \& Tata (1981) \\
\hline $23 \mathrm{G}$ & $\mathrm{Glt}^{-} \mathrm{Gdh}^{-}$ & SU1 & This paper \\
\hline SU4(6) & $\mathrm{Glt}^{-} \mathrm{Gdh}^{-}$ & SU4 & This paper \\
\hline SU4(8) & Glt $^{-} \mathrm{Gdh}^{-}$ & SU4 & This paper \\
\hline & $\mathrm{Glt}^{-} \mathrm{GdhR}^{-}$ & SU1 & Brown \& Tata (1981) \\
\hline Glum2 & $\mathrm{Glt}^{-} g d h A 2$ & SU4 & This paper \\
\hline $2 \mathrm{U} 2$ & $\mathrm{Glt}^{-} \mathrm{gdhA} \mathrm{GdhR}^{-}$ & Glum2 & This paper \\
\hline
\end{tabular}

$P A G E$. Native polyacrylamide gels were prepared and run using the discontinuous buffer system described by Davis (1964). To detect NADP-GDH activity after electrophoresis, gels were immersed in a solution prepared by mixing 1 vol. of an aqueous solution containing $1 \mathrm{mg}$ phenazine methosulphate (PMS) $\mathrm{ml}^{-1}$ and $1 \mathrm{mg} \mathrm{3-(4,5-}$ dimethylthiazol-2-yl)-2,5-diphenyltetrazolium bromide) (MTT) $\mathrm{ml}^{-1}$ and $10 \mathrm{vols}$ of the standard assay mixture used to determine deaminating activity. NADP-GDH activity was visualized as dark blue zones produced by formazan formation.

Electrophoresis and detection of NADP-GDH activity on cellulose acetate gels. Extracts $(2-5 \mu \mathrm{l})$ were applied as a narrow line at the origins of cellulose acetate strips (Shandon). After electrophoresis for $90 \mathrm{~min}$ in $0.05 \mathrm{M}$-barbitone buffer, $\mathrm{pH} 8.5$, strips were layered on top of gels prepared by mixing equal volumes of melted $1 \%(\mathrm{w} / \mathrm{v})$ Difco Noble Agar in water and $50 \mathrm{mM}$ Tris-HCl, pH 7.6, containing $1 \mathrm{~mm}-\mathrm{NADP}, 1 \mathrm{mg} \mathrm{PMS} \mathrm{ml} \mathrm{m}^{-1}, 1 \mathrm{mg} \mathrm{MTT} \mathrm{ml}^{-1}$ and $100 \mathrm{mM}$-sodium L-glutamate. NADP-GDH activity was detected after a few minutes incubation at $37^{\circ} \mathrm{C}$ as dark blue lines produced by formazan formation.

Enzyme assays. NADP-GDH aminating activity. Enzyme was added to a mixture $(1 \mathrm{ml})$ containing $50 \mathrm{~mm}$ Tris $/ \mathrm{HCl}, \mathrm{pH} 7.5,10 \mathrm{~mm}$ neutralized 2-oxoglutarate and $0.25 \mathrm{~mm}-\mathrm{NADPH}$ equilibrated at $37^{\circ} \mathrm{C}$. The reaction was initiated by addition of a solution of ammonium chloride (final concentration $50 \mathrm{~mm}$ ), and the rate of decrease of absorbance at $340 \mathrm{~nm}$ was measured in an SP 800 recording spectrophotometer (Pye Unicam). The molar absorbance coefficient used for NADPH was $6.22 \times 10^{3} 1 \mathrm{~mol}^{-1} \mathrm{~cm}^{-1}$ at $340 \mathrm{~nm}$.

NADP-GDH deaminating activity. Enzyme was added to $1 \mathrm{ml}$ assay mixture containing $50 \mathrm{~mm}-\mathrm{Tris} / \mathrm{HCl}$, $\mathrm{pH} 7.5$, and $1 \mathrm{~mm}-\mathrm{NADP}^{+}$equilibrated at $37^{\circ} \mathrm{C}$. The reaction was initiated by addition of sodium L-glutamate to give a final concentration of $100 \mathrm{~mm}$. Enzyme activity was measured as the increase in absorbance at $340 \mathrm{~nm}$.

Glutamate synthase (EC 1.4.1.13) was assayed by the method of Meers et al. (1970).

Glutamate synthetase (GS; EC 6.3.1.2) was assayed by its glutamyltransferase activity as described by Brown \& Tata (1981). Non-adenylylated GS was estimated by assaying in the presence of $60 \mathrm{mM}-\mathrm{MgCl}_{2}$.

Enzyme activities are expressed as nmol product $\min ^{-1}$ (mg protein) ${ }^{-1}$.

Estimation of protein. The protein in cell free extracts and throughout the purification of NADP-GDH was determined by the Lowry method using bovine serum albumin as standard.

Estimation of intracellular amino acid pools. Samples of $10 \mathrm{ml}$ (exponential phase) cultures were passed through pre-weighed glassfibre Millipore filters $(45 \mu \mathrm{m})$ contained in a sintered filter system. The cells were washed on the filters with $2 \mathrm{ml}$ dilution buffer. The process was done in duplicate for each sample. One of the pair of samples was placed in an oven at $80^{\circ} \mathrm{C}$ for $30 \mathrm{~min}$ and the paper reweighed to determine the dry weight of bacteria. The other filter was placed in $1 \mathrm{ml}$ ice-cold $6 \%(\mathrm{w} / \mathrm{v})$ perchloric acid with $30 \mathrm{nmol}$ norleucine added as internal standard. Cells were left for $5 \mathrm{~min}$ before adding $200 \mu \mathrm{l} 2 \mathrm{M}$-potassium carbonate. The precipitate of potassium chlorate was removed by centrifugation. The supernatant solution was acidified with $10 \mu \mathrm{l} 1 \mathrm{M}-\mathrm{HCl}$ and the amino acid composition was analysed using a Locarte automatic amino acid analyser.

Bacteriophage and transduction. Lysates of bacteriophage F116 (Holloway et al., 1969) were prepared and transduction was done essentially as described by Brammar et al. (1962).

Isolation of glutamate auxotrophs. After mutagenesis of Glt ${ }^{-}$strains with $N$-methyl- $N^{\prime}$-nitrosoguanidine (NTG) (Brammar et al., 1967) cultures were diluted and plated either on nutrient agar or S/pro medium to give about 100 colonies per plate. After overnight (on nutrient medium) or $36 \mathrm{~h}$ (on S/Pro medium) growth at $37^{\circ} \mathrm{C}$, colonies were replicated onto $\mathrm{S} / \mathrm{N}$ solid medium using the medium of Lederberg \& Lederberg (1952). Colonies unable to grow on S/N medium were picked. Strains SU4(6) and SU4(8) were isolated in separate experiments. 
Isolation of strain Glum2. Strain SU4 was treated with NTG as described above, grown overnight in nutrient broth at $37^{\circ} \mathrm{C}$ then plated to give about 100 colonies per plate on nutrient agar. Plates were incubated at $37^{\circ} \mathrm{C}$ for $24 \mathrm{~h}$ then replicated onto $\mathrm{S} / \mathrm{N}$ plates at $45^{\circ} \mathrm{C}$. Colonies not growing on $\mathrm{S} / \mathrm{N}$ were picked from nutrient agar then patched onto $\mathrm{S} /$ Pro and $\mathrm{S} / \mathrm{N}$ plates.

Materials. 2',5'-ADP agarose, Reactive Red agarose, NAD(P)H, NADP + , 2-oxoglutarate, Coomassie Blue and streptomycin sulphate were obtained from Sigma. DEAE Sepharose and Sephadex G200 were from Pharmacia. Acrylamide (specially purified for electrophoresis), bisacrylamide AR grade, ammonium persulphate AR grade and ammonium sulphate (low in heavy metals) were from BDH.

\section{RESULTS}

\section{Purification of NADP-GDH}

NADP-GDH was purified from $P$. aeruginosa strain 8602 with a yield of $70 \%$; a summary of the purification is given in Table 2 . The purified enzyme preparation produced a single proteinstaining band after PAGE at loadings of up to $200 \mu \mathrm{g}$ protein (Fig. 1). Similar gels cut and stained, half for protein, half for enzyme activity, showed that NADP-GDH activity was associated with the protein-staining band. Several variations in the purification procedure were tried without improving the yield or purity of the product; omission of the Reactive Red column stage gave a product shown by PAGE to contain only one other protein in addition to NADPGDH. The enzyme was maintained in $50 \%(\mathrm{v} / \mathrm{v})$ glycerol at $4{ }^{\circ} \mathrm{C}$ with no loss of activity after 1 year.

\section{$M_{r}$ determination}

The $M_{\mathrm{r}}$ of the native enzyme was estimated to be 280000 by Sephadex G-200 gel filtration. Examination of the purified enzyme by SDS-PAGE revealed a single band after staining for protein. The $M_{\mathrm{r}}$ of the subunit, determined by reference to marker proteins, was 45000 .

\section{Isolation of mutant strains lacking NADP-GDH}

In order to investigate the metabolic role of NADP-GDH, strains auxotrophic for glutamate were isolated from the $\mathrm{Glt}^{-}$parent strains SU1 and SU4.

After mutagenesis, several colonies were obtained that were able to grow on nutrient or $\mathrm{S} / \mathrm{Pro}$ medium but unable to grow on $\mathrm{S} / \mathrm{N}$ medium. These were further tested by patching onto $\mathrm{S} / \mathrm{N}$ and S/Glu media. Mutant strains SU4(6), SU4(8) and 23G grew on S/Glu medium. Growth properties of these strains were similar and are compared with those of parental strains in Table 3. The characteristic of these strains was that they did not grow unless provided with glutamate as a nitrogen source or with a nitrogen source such as proline that is catabolized to form glutamate (Meile \& Leisinger, 1982). Failure to grow with histidine as nitrogen source despite the fact that glutamate is produced by breakdown of histidine in $P$. aeruginosa (Lessie \& Neidhardt, 1967) was not considered significant because the inability to use histidine as nitrogen source is associated with the loss of glutamate synthase (Brown \& Tata, 1981).

\section{Enzyme activities of glutamate auxotrophs}

Enzyme assays were done on cell extracts from the glutamate auxotrophs to see if their phenotypes were linked to loss of NADP-GDH activity. In order to select a nitrogen source that would support growth of the mutants but would not be expected to repress the synthesis of NADP-GDH, NADP-GDH activities were measured in the wild-type organism grown on a variety of appropriate nitrogen sources (Table 4). The highest NADP-GDH activity was found in strain 8602 grown on medium containing glutamine.

Assays were done on the mutant strains grown in S/Gln medium and in no case was NADPGDH activity detected. Comparisons of NAD-GDH and GS activities in strain 23G with those of its ancestral strains showed no significant differences (Table 4). Similarly, comparisons of enzyme activities during growth in S/Pro and S/Glu media confirmed that strain 23G lacked NADP-GDH activity but was indistinguishable from its parental strains with respect to NADGDH and GS (data not shown). 
Table 2. Purification of NADP-GDH from P. aeruginosa strain PAC 1

An enzyme unit is the amount catalysing the formation of $1 \mu$ mol product min $^{-1}$.

\begin{tabular}{|c|c|c|c|c|}
\hline $\begin{array}{l}\text { Purification } \\
\text { stage }\end{array}$ & $\begin{array}{l}\text { Vol. } \\
(\mathrm{ml})\end{array}$ & $\begin{array}{c}\text { Total } \\
\text { protein }(\mathrm{mg})\end{array}$ & $\begin{array}{c}\text { Total } \\
\text { enzyme units }(U)\end{array}$ & $\begin{array}{l}\text { Specific activity } \\
\text { U (mg protein) }\end{array}$ \\
\hline $\begin{array}{l}\text { Streptomycin } \\
\text { precipitation }\end{array}$ & 167 & 2171 & 281 & $0 \cdot 13$ \\
\hline $\begin{array}{l}60 \%\left(\mathrm{NH}_{4}\right)_{2} \mathrm{SO}_{4} \\
\text { precipitate }\end{array}$ & 96 & 672 & 240 & $0 \cdot 36$ \\
\hline DEAE Sepharose & 22 & 78 & 230 & $3 \cdot 0$ \\
\hline $\begin{array}{l}\text { Reactive Red } \\
\text { Sepharose }\end{array}$ & $3 \cdot 0$ & 6 & 201 & $33 \cdot 5$ \\
\hline $\begin{array}{l}2^{\prime}, 5^{\prime}-\mathrm{ADP} \\
\text { agarose }\end{array}$ & 1.0 & 0.97 & 196 & 201 \\
\hline
\end{tabular}

Table 3. Comparison of growth properties of P. aeruginosa glutamate auxotrophs and their parent strains

+ , Single colonies after $24 \mathrm{~h}$ at $37^{\circ} \mathrm{C}$ and $25^{\circ} \mathrm{C}$; - , no colonies after $72 \mathrm{~h}$ at either $37^{\circ} \mathrm{C}$ or $25^{\circ} \mathrm{C}$.

Growth of bacterial strains

$\begin{array}{lccc} & & & \\ \text { Medium } & \text { AIU1N/8602 } & \text { SU4/SU1 } & \text { 23G/SU4(6)/SU4(8) } \\ \text { S/N } & + & + & - \\ \text { S/Glu } & + & + & + \\ \text { S/Gln } & + & + & + \\ \text { S/Pro } & + & + & + \\ \text { S/His } & + & - & - \\ \text { S/Nit } & + & - & - \\ \text { S/lowN } & + & & -\end{array}$

Table 4. Enzyme activities in P. aeruginosa strains growing on various nitrogen sources

Enzyme activities were determined on extracts prepared from cells harvested in mid-exponential phase. Results are means; assays were done in duplicate or triplicate and agreed within $\pm 15 \%$. ND, Not determined.

\begin{tabular}{|c|c|c|c|c|c|c|}
\hline \multirow[b]{2}{*}{ Strain } & \multirow{2}{*}{ Medium } & \multirow[b]{2}{*}{$\begin{array}{c}\text { Doubling } \\
\text { time } \\
\text { (min) }\end{array}$} & \multicolumn{4}{|c|}{$\begin{array}{c}\text { Enzyme activities } \\
{\left[\text { nmol product } \min ^{-1}(\mathrm{mg} \text { protein })^{-1}\right]}\end{array}$} \\
\hline & & & $\begin{array}{l}\text { NADP- } \\
\text { GDH }\end{array}$ & $\begin{array}{l}\text { NAD- } \\
\text { GDH }\end{array}$ & $\begin{array}{l}\text { Glutamate } \\
\text { synthase }\end{array}$ & GS \\
\hline \multirow[t]{5}{*}{8602} & $\mathbf{S} / \mathbf{N}$ & 60 & 107 & 255 & 77 & 72 \\
\hline & S/Gln & 30 & 105 & 200 & 52 & 78 \\
\hline & S/Glu & 55 & 10 & 284 & 61 & 92 \\
\hline & S/Pro & 66 & 10 & 132 & 20 & 572 \\
\hline & $\mathrm{S} / \mathrm{His}$ & 54 & 30 & 120 & 74 & 1292 \\
\hline AIUIN & S/Gln & ND & 107 & 140 & 52 & ND \\
\hline SUl & S/GIn & 45 & 139 & 189 & 0 & 79 \\
\hline $23 \mathrm{G}$ & $\mathrm{S} / \mathrm{Gln}$ & 65 & 0 & 178 & 0 & 97 \\
\hline
\end{tabular}

\section{Revertants of strain $23 G$}

The frequency of reversion of strain $23 \mathrm{G}$ to glutamate independence was investigated to determine whether it was low enough for transduction studies to be done and to gain information about the nature of the mutation responsible for glutamate auxotrophy. Reversion was examined on $\mathrm{S} / \mathrm{N}, \mathrm{S} /$ nit and $\mathrm{S} /$ low $\mathrm{N}$ media. On each medium the number of colonies obtained after $72 \mathrm{~h}$ incubation at $37^{\circ} \mathrm{C}$ was about 3 per $2 \times 10^{8}$ cells plated. Several revertants were picked and patched onto $\mathrm{S} / \mathrm{N}, \mathrm{S} /$ nit and $\mathrm{S} /$ low $\mathrm{N}$ media. No matter on which medium they 


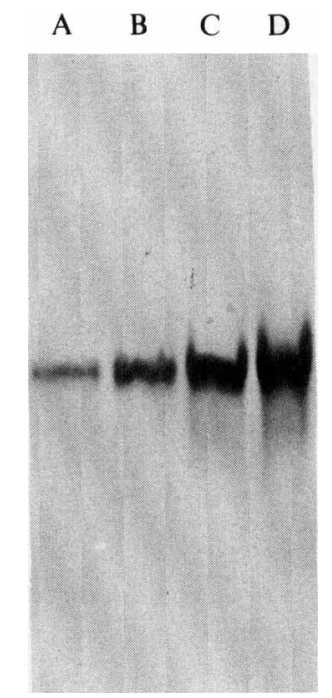

Fig. 1. PAGE of purified NADP-GDH. Lanes A-D contained 20,50,100 and $200 \mu \mathrm{g}$ respectively purified enzyme. The gel was stained with Coomassie Blue.

originated, all revertants, including 80 isolated on $\mathrm{S} / \mathrm{N}$ medium, grew on $\mathrm{S} /$ nit and $\mathrm{S} /$ lowN media. Since strain SU1 is unable to grow on the latter two media it seemed likely that growth of revertants was associated with the restoration of glutamate synthase activity. To verify this, five revertants were grown in $\mathrm{S} / \mathrm{N}$ medium and extracts were assayed for NADP-GDH and glutamate synthase. In each case glutamate synthase activity was detected and NADP-GDH activity was absent (data not shown). These results indicated that the mutation responsible for glutamate auxotrophy was not revertible at a detectable frequency and that restoration of glutamate synthase activity in the absence of NADP-GDH restored ability to grow on $\mathrm{S} / \mathrm{N}$ medium.

\section{Studies with transductants}

To investigate further the relationship between genotype and phenotype, glutamateindependent transductants were isolated from strain 23G, their growth properties examined and their enzyme activities measured. Phage F116 grown on strain AIU1N, the parent of strain SUl, was used to infect strain $23 \mathrm{G}$ and glutamate-independent transductants were selected on $\mathrm{S} / \mathrm{N}, \mathrm{S} /$ nit and $\mathrm{S} /$ low $\mathrm{N}$ media. The growth properties of the transductants were investigated further by patching each one onto $S / N, S /$ nit and $S /$ lowN media. The properties of typical transductants from each group are given in Table 5 . Those isolated on $\mathrm{S} /$ lowN or $\mathrm{S} /$ nit media grew on all three media. Several of these transductants were grown in $\mathrm{S} / \mathrm{N}$ medium and extracts were assayed for enzymes involved in nitrogen metabolism; in all cases glutamate synthase activity was restored but in no case was NADP-GDH activity detected (Table 5). GS activities were unaltered (data not shown). Of 18 transductants isolated on $\mathrm{S} / \mathrm{N}$ medium, seven were able to grow only on $\mathrm{S} / \mathrm{N}$ medium, the remainder grew on all three test media. All 18 transductants were grown in S/N medium and extracts were assayed for NADP-GDH and glutamate synthase.

The results, a representative selection of which are given in Table 5, clearly showed that restoration of NADP-GDH was associated with the ability to grow only on S/N and confirmed the conclusion derived from studies with revertants that glutamate synthase even in the absence of NADP-GDH restores the full repertoire of utilizable N-sources to P. aeruginosa. Plate tests with glutamate-independent transductants obtained on $\mathrm{S} / \mathrm{N}$ medium from strains SU4(6) and SU4(8) infected with phage F116 grown on strain 8602 gave similar results to those obtained with transductants derived from strain $23 \mathrm{G}$. 
Table 5. Properties of glutamate-independent transductants from P. aeruginosa strain $23 G$

\begin{tabular}{|c|c|c|c|c|c|c|c|}
\hline \multirow[b]{3}{*}{ Strain } & \multirow{3}{*}{$\begin{array}{c}\text { Selection } \\
\text { medium }\end{array}$} & \multirow{2}{*}{\multicolumn{3}{|c|}{ Growth properties on:* }} & \multicolumn{3}{|c|}{$\begin{array}{c}\text { Enzyme activities } \dagger \\
{\left[\mathrm{nmol} \text { product } \mathrm{min}^{-1}(\mathrm{mg} \text { protein })^{-1}\right]}\end{array}$} \\
\hline & & & & & \multirow{2}{*}{$\begin{array}{l}\text { NADP- } \\
\text { GDH }\end{array}$} & \multirow{2}{*}{$\begin{array}{l}\text { Glutamate } \\
\text { synthase }\end{array}$} & \multirow{2}{*}{$\begin{array}{l}\text { NAD- } \\
\text { GDH }\end{array}$} \\
\hline & & $\mathbf{S} / \mathbf{N}$ & S/nit & S/lowN & & & \\
\hline AIU1N & & + & + & + & 127 & 76 & 143 \\
\hline SU1 & & + & - & - & 145 & 0 & 230 \\
\hline \multicolumn{8}{|c|}{ Transductants } \\
\hline $\mathrm{Tl}$ & S/nit & + & + & + & 0 & 90 & 170 \\
\hline $\mathrm{T} 2$ & S/nit & + & + & + & 0 & 72 & 153 \\
\hline $\mathrm{Ll}$ & S/lowN & + & + & + & 0 & 71 & 180 \\
\hline $\mathrm{L} 2$ & S/lowN & + & + & + & 0 & 54 & 161 \\
\hline SN1 & $\mathbf{S} / \mathbf{N}$ & + & + & + & 0 & 53 & 200 \\
\hline SN15 & $\mathbf{S} / \mathbf{N}$ & + & + & + & 0 & 81 & 158 \\
\hline SN8 & $\mathbf{S} / \mathbf{N}$ & + & - & - & 128 & 0 & 170 \\
\hline SN3 & $\mathbf{S} / \mathbf{N}$ & + & - & - & 192 & 0 & 220 \\
\hline SN6 & $\mathbf{S} / \mathbf{N}$ & + & - & - & 134 & 0 & 164 \\
\hline
\end{tabular}

Growth rates of a variety of revertants and transductants derived from strain $23 \mathrm{G}$ that were $\mathrm{Glt}^{+} \mathrm{Gdh}^{-}$on S/N, S/Gln and S/Pro media showed no significant differences in doubling times when compared with strain AIU1N $\left(\mathrm{Glt}^{+} \mathrm{Gdh}^{+}\right)$(data not shown).

\section{NADP-GDH activity in strain 39}

Strain 39 is a spontaneous mutant, which, like its parent strain SU1, lacks glutamate synthase but can utilize more nitrogen sources than its parent through a mutation causing it to have high NADP-GDH activity (Brown \& Tata, 1981). To investigate whether the mutation in strain 39 responsible for the high NADP-GDH activity was located in the $g d h A$ gene NADP-GDH was purified from strain 39 and its physicochemical and kinetic properties were compared with those of enzyme purified from strain 8602 . In specific activities, $K_{\mathrm{m}}$ values, $M_{\mathrm{r}}$, pH optima, heat stability and electrophoretic mobilities the two purified enzymes were indistinguishable (data not shown). In order to gain some idea of the nature of the mutation responsible, the effects of various nitrogen sources on NADP-GDH activity were compared for strain 39, its parent strain SU1 and the wild-type organism 8602 in exponential and stationary phase cultures (Table 6). With glutamate as nitrogen source instead of ammonia strain 8602 showed a ninefold reduction in NADP-GDH activity but there was only a twofold reduction in strain 39 . Because they lack glutamate synthase, neither strain 39 nor its parent SU1 is able to grow under conditions of ammonia limitation so it was not possible to compare NADP-GDH activities under these circumstances. Growth in medium with proline as nitrogen source caused some derepression of GS and a steep decline in NADP-GDH activity in the wild-type organism but had much less effect in strain 39 . Since proline is converted directly to glutamate in $P$. aeruginosa some effect on NADP-GDH through high intracellular glutamate concentration might be expected.

In order to see whether the high NADP-GDH activity in strain 39 was attributable to a reduction in intracellular glutamate concentration, the concentration of glutamate was determined for cells of the three strains in $\mathrm{S} / \mathrm{N}$ and $\mathrm{S} / \mathrm{Pro}$ media (Table 6). The results showed no significant differences in glutamate concentration between strain SU1 and 39 in either medium. Neither were differences observed between the two strains in the concentrations of any other amino acids (glutamine was not determined). Glutamate concentrations were 10-fold higher than those of any other amino acid in ammonia-grown cells and 15-fold higher in proline-grown cells (proline concentrations were not determined). As anticipated glutamate concentrations in proline-grown cells were much higher (by a factor of six) than in ammonia-grown ones. 
Table 6. Effects of nitrogen source on enzyme activities and intracellular glutamate concentrations in P. aeruginosa strains 8602, SU1 and 39

\begin{tabular}{|c|c|c|c|c|c|}
\hline \multirow[b]{3}{*}{ Strain } & \multirow{3}{*}{$\begin{array}{l}\text { Growth } \\
\text { medium }\end{array}$} & \multicolumn{3}{|c|}{$\begin{array}{c}\text { Enzyme activities* } \\
\left.\text { [nmol product } \min ^{-1}\left(\mathrm{mg}^{*} \text { protein }\right)^{-1}\right]\end{array}$} & \multirow{3}{*}{$\begin{array}{l}\text { Intracellula } \\
\text { glutamate } \\
\text { concn } \dagger \\
(\mathrm{mM})\end{array}$} \\
\hline & & \multirow[b]{2}{*}{ NADP-GDH } & \multicolumn{2}{|c|}{ GS } & \\
\hline & & & $-\mathrm{Mg}^{2+}$ & $+\mathrm{Mg}^{2+}$ & \\
\hline $\begin{array}{l}8602 \\
\text { SU1 } \\
39\end{array}$ & $\mathbf{S} / \mathbf{N}$ & $\begin{array}{r}107 \\
114 \\
1260\end{array}$ & $\begin{array}{r}72 \\
121 \\
93\end{array}$ & $\begin{array}{r}33 \\
<10 \\
<10\end{array}$ & $\begin{array}{r}14 \cdot 5 \\
5 \cdot 5 \\
4 \cdot 0\end{array}$ \\
\hline $\begin{array}{l}8602 \\
\text { SU1 } \\
39\end{array}$ & S/Glu & $\begin{array}{r}12 \\
12 \\
750\end{array}$ & $\begin{array}{l}92 \\
70 \\
95\end{array}$ & $\begin{array}{r}55 \\
<10 \\
<10\end{array}$ & $\begin{array}{l}\text { ND } \\
\text { ND } \\
\text { ND }\end{array}$ \\
\hline $\begin{array}{l}8602 \\
\text { SU1 } \\
39\end{array}$ & S/Pro & $\begin{array}{r}21 \\
10 \\
590\end{array}$ & $\begin{array}{r}572 \\
1024 \\
936\end{array}$ & $\begin{array}{r}310 \\
280 \\
30\end{array}$ & $\begin{array}{l}28 \cdot 3 \\
31 \cdot 0 \\
39 \cdot 0\end{array}$ \\
\hline
\end{tabular}

ND, Not determined.

* Results are means; assays were done in duplicate or triplicate and agreed within $\pm 15 \%$.

$\dagger$ Based on $2 \mu \mathrm{l} \mathrm{H}_{2} \mathrm{O}$ (mg dry wt cells) ${ }^{-1}$ (Farin, 1977).

We concluded from these observations that the mutation in strain 39 was not located in the gdhA gene but affected the regulation of synthesis of NADP-GDH.

\section{Genetic linkage of mutations affecting NADP-GDH synthesis}

Transduction experiments were done to see if the mutation in strain 39 causing derepression of NADP-GDH synthesis mapped close to mutations that resulted in loss of NADP-GDH activity. Phage F116 grown on strain 39 was used to infect strains 23G, SU4(6) and SU4(8), and transductants were selected on $\mathrm{S} / \mathrm{N}$ medium. Thirty-six transductants from the cross with strain 23G and 16 and 17 respectively from the transductions with strains SU4(6) and SU4(8) were tested for growth on S/nit medium; none grew indicating that they were all Git ${ }^{-}$strains. Twelve transductants from the cross with strain $23 \mathrm{G}$ were selected at random, grown in $\mathrm{S} / \mathrm{N}$ medium and assayed to compare NADP-GDH, glutamate synthase and GS activities with those of strain 39. The results are shown in Table 7 where they are contrasted with those for a typical $\mathrm{Gdh}^{+} \mathrm{Glt}^{-}$ transductant obtained on $\mathrm{S} / \mathrm{N}$ medium after infecting strain $23 \mathrm{G}$ with phage grown on strain AIU1N $\left(\mathrm{Glt}^{+} \mathrm{Gdh}^{+}\right)$. The data clearly show that transductants derived from strain 39 have the derepressed NADP-GDH synthesis characteristic of that strain. Transductants derived from strains SU4(6) and SU4(8) were chosen at random and again showed the high NADP-GDH levels characteristic of the donor strain (data not shown). These data provided evidence that the mutations eliminating NADP-GDH activity in strain SU4(6), SU4(8) and 23G were closely linked to the mutation in strain 39 causing derepression of NADP-GDH synthesis. The data also showed no evidence of linkage between the $\mathrm{Gdh}^{-}$and $\mathrm{Glt}^{-}$mutations and indicated that the $\mathrm{Glt}^{-}$mutations in strains SU4 and SU1 were close together since no $\mathrm{Glt}^{+}$recombinants were discovered among the transductants obtained from crosses between strains 39, SU4(6) and SU4(8).

\section{$A$ mutant strain producing an altered NADP-GDH}

In order to have a genetic marker for the $g d h A$ gene to see if the mutations affecting NADPGDH synthesis in strain 39 and the $\mathrm{Gdh}^{-}$mutants were linked to the $g d h A$ gene, a mutant producing an altered NADP-GDH was isolated. The protocol used was designed to isolate a mutant producing a temperature-sensitive NADP-GDH that would be a glutamate auxotroph at the non-permissive temperature $\left(45^{\circ} \mathrm{C}\right)$ but able to grow at $30^{\circ} \mathrm{C}$. From strain SU4 a mutant strain Glum 2 that grew well on S/Pro at $45^{\circ} \mathrm{C}$ after $24 \mathrm{~h}$ but poorly at $30^{\circ} \mathrm{C}$ on S/N medium after $72 \mathrm{~h}$ was isolated. 


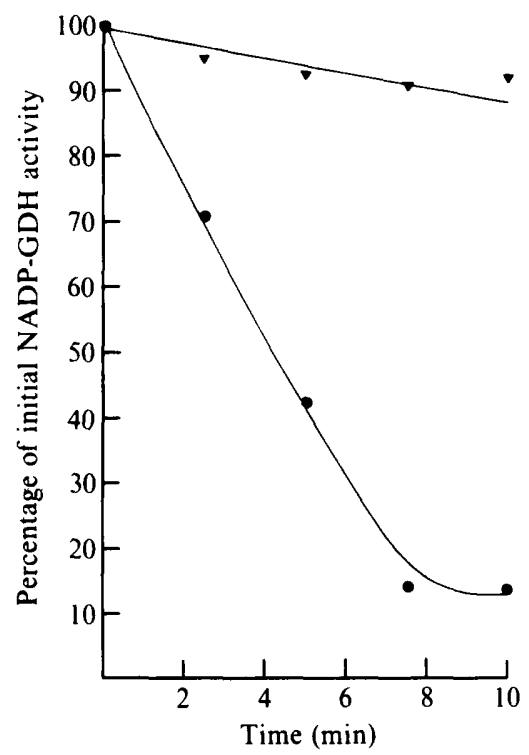

Fig. 2

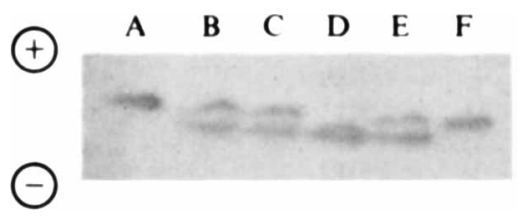

Fig. 3

Fig. 2. Comparison of heat sensitivities of NADP-GDH in cell-free extracts from strains SU4 ( $\nabla)$ and Glum2 (O). Cells were grown in $100 \mathrm{ml} \mathrm{S} / \mathrm{Gln}$ medium and extracts prepared in $0.5 \mathrm{ml} 50 \mathrm{~mm}$-Tris/ $\mathrm{HCl}$ buffer, pH 7.5. Samples $(100 \mu l)$ of extracts were incubated at $53^{\circ} \mathrm{C}$ for timed periods then cooled on ice and assayed for residual NADP-GDH activity. Initial activities of extracts were: SU4; $3 \cdot 6 \mu \mathrm{mol}$ product $\min ^{-1} \mathrm{ml}^{-1}\left(13.7 \mathrm{mg}\right.$ protein $\left.\mathrm{ml}^{-1}\right)$; Glum2, $0.6 \mu \mathrm{mol}$ product $\mathrm{min}^{-1} \mathrm{ml}^{-1}(11.4 \mathrm{mg}$ protein $\mathrm{ml}^{-1}$ ).

Fig. 3. NADP-GDH in transductants $(t)$ isolated on $S / N$ medium from the cross F116.2U2 $\times \mathrm{SU}(4)$ examined by electrophoresis on cellulose acetate. Extracts were made from bacteria grown in $S / N$ medium. After electrophoresis, gels were stained for NADP-GDH activity which is revealed as dark bands in the Figure. Extracts were: lane A, SU4; B, SU4 + t2; C, SU4 + t3; D, 2U2; E, SU4 + t5; F, SU4.

Strain Glum2 resembled its parent in growing normally when supplied with nitrogen as glutamate or a glutamate precursor such as glutamine or proline but growth of single colonies on $\mathrm{S} / \mathrm{N}$ medium, normally observed after $36 \mathrm{~h}$ at $37^{\circ} \mathrm{C}$ for the parent strain was extremely slow, colonies eventually appearing after $10 \mathrm{~d}$. Measurements of NADP-GDH aminating activity from extracts of cells grown in S/Gln medium showed that Glum2 had approximately one-fifth the activity of the parent strain. A comparison of the heat sensitivities of the enzymes from parent and mutant strains showed NADP-GDH activity in strain Glum 2 to be thermolabile at $53^{\circ} \mathrm{C}$ whereas the wild-type enzyme was stable (Fig. 2). The two enzymes also differed in the ratio of activities in the forward and reverse reactions they catalysed. The ratios aminating: deaminating were 3.5:1 (SU4) and 1.7:1 (Glum2). In addition, NADP-GDH from Glum2 had reduced electrophoretic mobility compared with the enzyme from SU4 (Fig. 3).

To obtain evidence that the $\mathrm{Gdh}^{-}$mutations in strains SU4(6), SU4(8) and 23G were all linked to the $g d h A$ gene, transduction experiments were done in which these strains were recipients and strain Glum 2 was the donor. Selection was made for glutamate prototrophs on $\mathrm{S} / \mathrm{N}$ medium; however, no transductants were obtained. We tentatively concluded that this was due to the very slow growth rate expected of transductants inheriting the altered structural gene of strain Glum2.

\section{Transduction with a derivative of strain Glum2 producing high levels of NADP-GDH}

Although failure to obtain prototrophic transductants with strain Glum2 as donor could be interpreted as evidence that the $\mathrm{Gdh}^{-}$mutations in the glutamate auxotrophic strains did not lie outside the $g d h A$ gene, more positive evidence was sought by using as donor strain a mutant 
Table 7. Enzyme activities in extracts of transductants obtained from the cross $39(F 116) \times 23 G$

Cells were grown in $\mathrm{S} / \mathrm{N}$ medium.

\begin{tabular}{|c|c|c|c|c|}
\hline \multirow[b]{3}{*}{ Strain } & \multicolumn{4}{|c|}{$\begin{array}{c}\text { Enzyme activities* } \\
\left.\text { [nmol product } \mathrm{min}^{-1}(\mathrm{mg} \text { protein })^{-1}\right]\end{array}$} \\
\hline & \multirow[b]{2}{*}{ NADP-GDH } & \multirow[b]{2}{*}{$\begin{array}{l}\text { Glutamate } \\
\text { synthase }\end{array}$} & \multicolumn{2}{|c|}{$\underbrace{G S}$} \\
\hline & & & $-\mathrm{Mg}^{2+}$ & $+\mathrm{Mg}^{2+}$ \\
\hline AIU1N & 127 & 76 & 128 & 42 \\
\hline SN2† & 120 & 0 & 85 & 20 \\
\hline 39 & 1273 & 0 & 104 & 30 \\
\hline \multicolumn{5}{|c|}{ Transductants } \\
\hline $39 \mathrm{H} 1$ & 965 & 0 & 85 & $<10$ \\
\hline $39 \mathrm{H} 2$ & 965 & 0 & 50 & $<10$ \\
\hline $39 \mathrm{H} 3$ & 965 & 0 & 85 & $<10$ \\
\hline $39 \mathrm{H} 4$ & 1072 & 0 & 85 & $<10$ \\
\hline $39 \mathrm{H} 5$ & 1200 & 0 & 73 & $<10$ \\
\hline $39 \mathrm{H} 6$ & 1452 & 0 & 96 & $<10$ \\
\hline $39 \mathrm{H} 7$ & 965 & 0 & ND & ND \\
\hline $39 \mathrm{H} 8$ & 1452 & 0 & ND & ND \\
\hline $39 \mathrm{H} 9$ & 1321 & 0 & ND & ND \\
\hline $39 \mathrm{H} 10$ & 890 & 0 & ND & ND \\
\hline $39 \mathrm{H} 1 \mathrm{l}$ & 890 & 0 & ND & ND \\
\hline $39 \mathrm{H} 12$ & 965 & 0 & ND & ND \\
\hline
\end{tabular}

ND, Not determined.

* Results are means; assays were done in duplicate or triplicate and agreed to within $15 \%$.

$+\mathrm{SN} 2$ is a glutamate-independent transductant obtained on $\mathrm{S} / \mathrm{N}$ medium from the cross F116. AIU1N $\times 23 \mathrm{G}$.

producing high levels of altered NADP-GDH in transduction experiments with the glutamate auxotrophs. We anticipated obtaining such strains by selecting for mutants from strain Glum2 that were able to grow on $\mathrm{S} / \mathrm{U}$ medium. We had observed that strain 39 grew slowly on $\mathrm{S} / \mathrm{U}$ solid medium and we have isolated several spontaneous mutants on this medium from strain SU4, a high proportion of which, like strain 39 , were unable to grow on $\mathrm{S} /$ nit medium, lacked glutamate synthase and produced levels of NADP-GDH on all media 10-fold or more higher than strain 8602 (P. R. Brown \& R. Tata, unpublished results). From about $10^{8}$ cells of strain Glum2 plated on S/U medium five fast growing colonies were picked after several days incubation at $37^{\circ} \mathrm{C}$. None was able to grow on $\mathrm{S} /$ nit medium and all, after growth on $\mathrm{S} / \mathrm{N}$ medium, had about nine times the NADP-GDH activity of the parent (data not shown). In each case the NADP-GDH synthesized had the same altered electrophoretic mobility as that of Glum2 with similar ratios of aminating:deaminating activity. These mutants thus appeared to be derepressed for synthesis of altered NADP-GDH. One of the mutant strains, 2U2, was chosen arbitrarily as the donor in transduction experiments with the glutamate auxotroph SU4(6) as recipient. Seventy transductants were obtained on $\mathrm{S} / \mathrm{N}$ medium after $4 \mathrm{~d}$ incubation at $37^{\circ} \mathrm{C}$. Extracts from six transductants grown in $\mathbf{S} / \mathrm{N}$ medium were examined by electrophoresis. All clearly produced NADP-GDH with the altered mobility characteristic of the donor strain (Fig. 3).

\section{DISCUSSION}

The $M_{\mathrm{r}}(280000)$ of the NADP-GDH from $P$. aeruginos $a$ is similar to that of enzymes from several other micro-organisms (Coulton \& Kapoor, 1973; Hemmila \& Mantsala, 1978; Hooper et al., 1967; Sakomoto et al., 1975; Shiio \& Osaki, 1970); the subunit $M_{\mathrm{r}}$ indicates that it is composed of six subunits like the enzymes from E. coli (Sakomoto et al., 1975) and Bacillus megaterium (Hemmila \& Mantsala, 1978). Smits et al. (1984) reported the purification of NADPGDH from P. aeruginosa strain PAO1 : although specific activities of the enzymes from PAOl 
and strain PAC 1 are very similar and hexameric structures are proposed for both, there is a significant difference in the reported $M_{\mathrm{r}}$ values, the latter authors giving a value of 325000 .

The glutamate dependency of strains $23 \mathrm{G}$, SU4(6) and SU4(8) shows that it is NADP-GDH that supports the growth of $\mathrm{Glt}^{-}$mutants on medium containing high concentrations of ammonia as nitrogen source. However, since $\mathrm{Glt}^{+} \mathrm{Gdh}^{-}$strains are able to grow on such a medium it seems that NADP-GDH is not an essential enzyme. In this respect it resembles the NADP-GDH of enteric organisms (Tyler, 1978). The repression of NADP-GDH activity in nitrogen-limiting media [as observed for NADP-GDH in $K$. pneumoniae (Brenchley \& Magasanik, 1973)] does suggest, however, that under growth conditions where ammonia is present in excess, NADP-GDH activity in the wild-type strain makes a contribution to glutamate synthesis; furthermore, it has an economic advantage over the GS/glutamate synthase pathway for glutamate synthesis in not requiring ATP. Since NAD-GDH synthesis was unaffected in the glutamate auxotroph, strain $23 \mathrm{G}$, we conclude that NAD-GDH activity does not produce glutamate, at least not at a rate compatible with growth. This supports previous suggestions (Janssen et al., 1980) that NAD-GDH in P. aeruginosa serves a catabolic role with regard to glutamate, analogous to that of the NAD-GDH from Saccharomyces cerevisiae (Pateman \& Kinghorn, 1976).

The mutation in strain $23 \mathrm{G}$ resulting in glutamate dependence and loss of NADP-GDH appeared non-revertible and therefore presumably is either a deletion or two or more closely linked mutations, but seems to affect specifically NADP-GDH synthesis; no changes in the synthesis of glutamate synthase, NAD-GDH or GS were observed. Evidence from transduction experiments indicates that the lesions responsible for loss of NADP-GDH activity in all three glutamate auxotrophs mentioned in this paper are repaired by DNA that includes the structural gene of NADP-GDH; whether the mutations are in the $g d h A$ gene or an adjacent regulatory region cannot be deduced from the data.

Since $\mathrm{Gdh}^{+}$transductants obtained with strains SU4(6), SU4(8) and 23G using strain 39 as donor all exhibit the derepression of NADP-GDH synthesis characteristic of strain 39 the mutation in strain 39 seems to be closely linked to the $g d h A$ gene although not in it since NADPGDH from strain 8602 and 39 were identical. The mutation in strain $2 U 2$ responsible for high NADP-GDH (altered) activity also appears to be co-transducible with the $g d h A$ gene. We cannot be certain in this case that a regulatory mutation is responsible for the elevated levels of altered NADP-GDH but the properties of the enzyme synthesized by the strain appear identical to those of its parent and the similarity of such mutants to strain 39 make it more likely that alterations to a regulator region rather than to the structural gene are responsible.

We are not aware that mutations causing derepression of NADP-GDH synthesis and linked to the NADP-GDH structural gene have been described for any other organisms suggesting that the regulatory region controlling synthesis of the enzyme in $P$. aeruginosa may have interesting and unusual features; we are now examining by cloning methods the DNA region in which the mutations are located, in order to clarify the mechanism of regulation of this enzyme in $P$. aeruginosa.

We are grateful to the SERC for the award of a studentship to C.J. We thank Amy Brown for her help in the preparation of the manuscript.

\section{REFERENCES}

ANDREWS, P. (1970). Estimation of molecular size and molecular weights of biological compounds. Methods of Biochemical Analysis 18, 1-53.

BERBERICH, M. A. (1972). A glutamate-dependent phenotype in $E$. coli $\mathrm{K} 12$; the result of two mutations. Biochemical and Biophysical Research Communications 47, 1498-1503.

Brammar, W. J. \& Clarke, P. H. (1964). Induction and repression of Pseudomonas aeruginosa amidase. Journal of General Microbiology 37, 307-319.
Brammar, W. J., Clarke, P. H. \& Skinner, A. J. (1967). Biochemical and genetic studies with regulator mutants of the Pseudomonas aeruginosa 8602 amidase system. Journal of General Microbiology 47, 87-102.

BRENCHLEY, J. \& MAGaSANIK, B. (1973). Regulation of the synthesis of enzymes responsible for glutamate formation in Klebsiella aerogenes. Journal of Biological Chemistry 248, 6122-6128.

Brenchley, J. \& Magasanik, B. (1974). Mutants of 
Klebsiella aerogenes lacking glutamate dehydrogenase. Journal of Bacteriology 117, 544-550.

Brown, C. M., MacDonald-Brown, D. S. \& StanLEY, S. O. (1973). The mechanism of nitrogen assimilation in Pseudomonads. Antonie van Leeuwenhoek 13, 89-98.

Brown, P. R. \& TATA, R. (1981). Growth of Pseudomonas aeruginosa mutants lacking glutamate synthase activity. Journal of Bacteriology 147, 193197.

Coulton, J. W. \& KaPOoR, M. (1973). Purification and properties of the glutamate dehydrogenase of Salmonella typhimurium. Canadian Journal of Microbiology 19, 427-438.

Davis, B. J. (1964). Disc electrophoresis. II. Methods and application to human serum proteins. Annals of the New York Academy of Sciences 121, 404-427.

Dendinger, S. M., Patel, L. G. \& Brenchley, J. E. (1980). Salmonella typhimurium mutants with altered glutamate dehydrogenase and glutamate synthase activities. Journal of Bacteriology 141, 190-198.

FARIN, F. (1977). Studies on the mechanism of regulation of amidase synthesis in Pseudomonas aeruginosa. $\mathrm{PhD}$ thesis, University of London, UK.

Gregoriou, M., Brown, P. R. \& TATA, R. (1977). Pseudomonas aeruginosa mutants resistant to urea inhibition of growth on acetanilide. Journal of Bacteriology 132, 377-384.

Hemmila, I. A. \& Mantsala, P. I. (1978). Purification and properties of glutamate synthase and glutamate dehydrogenase from Bacillus megaterium. Biochemical Journal 173, 45-52.

Holloway, B. W., Egan, J. B. \& Monk, M. (1960). Lysogeny in Pseudomonas aeruginosa. Australian Journal of Experimental Biology and Medical Science 38, 321-330.

HoOper, A. B., Hanson, J. \& Bell, R. (1967). Characterization of glutamate dehydrogenase from the ammonia oxidizing chemoautotroph Nitromonas europaea. Journal of Biological Chemistry 242, 288296.

JaNSSEN, D. B., OP DEN CAMP, H. J. M., LEA, P. J. M. \& VAN DER DRIFT, C. (1980). The enzymes of ammonia assimilation in Pseudomonas aeruginosa. Archives of Microbiology 124, 197-203.

Kelly, M. \& Clarke, P. H. (1962). An inducible amidase produced by a strain of Pseudomonas aeruginosa. Journal of General Microbiology 27, 316319.

LEDerberg, J. \& Lederberg, E. M. (1952). Replica plating and indirect selection of bacterial mutants. Journal of Bacteriology 63, 399-406.
Lessie, T. G. \& NeIDHART, F. C. (1967). Formation and operation of the histidine-degrading pathways in Pseudomonas aeruginosa. Journal of Bacteriology 93, 1800-1810.

MeERs, J. L., Tempest, D. W. \& Brown, C. M. (1970). 'Glutamine(amide): 2-oxoglutarate amino transferase oxido-reductase (NADP)', an enzyme involved in the synthesis of glutamate by some bacteria. Journal of General Microbiology 64, 187-194.

Meile, L. \& Leisinger, T. (1982). Purification and properties of the bifunctional proline dehydrogenase 1-pyrroline-5-carboxylate dehydrogenase from Pseudomonas aeruginosa. European Journal of Biochemistry 129, 67-75.

Mountain, A., McPherson, M. J., Baron, A. J. \& Wootton, J. C. (1985). The Klebsiella aerogenes glutamate dehydrogenase $(g d h A)$ gene: cloning, high-level expression and hybrid enzyme formation in Escherichia coli. Molecular and General Genetics 199, 141-145.

Pateman, J. A. \& Kinghorn, J. R. (1976). Nitrogen metabolism. In Filamentous Fungi, vol. 2, pp. 159 237. Edited by J. E. Smith \& D. Berry. London: Edward Arnold.

Sakomoto, N. A., Kotre, M. \& Savageau, M. H. (1975). Glutamate dehydrogenase from Escherichia coli: purification and properties. Journal of Bacteriology 124, 775-783.

SHIIO, I. \& OSAKI, H. (1970). Regulation of nicotinamide adenine dinucleotide phosphate specific glutamate dehydrogenase from Brevibacterium flavium, a glutamate-producing bacterium. Journal of Biochemistry 68, 633-647.

SmITS, R. A. M. M., PIEPER, F. R. \& VAN DER DRIFT, C. (1984). Purification of NADP-dependent glutamate dehydrogenase from Pseudomonas aeruginosa and immunochemical characterization of its in vivo inactivation. Biochimica et biophysica acta 801, 3239.

Tempest, D. W., Meers, J. L., Brown, C. M. (1970). Synthesis of glutamate in Aerobacter aerogenes by a hitherto unknown route. Biochemical Journal 117, 405-407.

TYLER, B. (1978). Regulation of the assimilation of nitrogen compounds. Annual Reviews of Biochemistry 47, 1127-1162.

WEBER, K. \& OSBORNE, M. (1969). The reliability of molecular weight determination by dodecyl sulphate-polyacrylamide gel electrophoresis. Journal of Biological Chemistry 244, 4406-4412. 